\title{
Economic representations in structure of economic consciousness of student youth in changing world: representations on wealth, poverty, property
}

\author{
A.N. Zakharova \\ Chuvash state University \\ Cheboksary, Russia \\ zaharova_an@mail.ru
}

\author{
T.V. Talanova \\ Chuvash state University \\ Cheboksary, Russia \\ tamaragoncharova@mail.ru

\section{M.V. Petrova} \\ Chuvash state University \\ Cheboksary, Russia
}

\author{
V.N. Chaynikov \\ Chuvash state University \\ Cheboksary, Russia
}

\begin{abstract}
In the modern changing world, a special scientific interest is the study of the economic consciousness of student youth as future managers of enterprises, firms and organizations, as potential entrepreneurs. Instability and complication of the economic environment of a person's life activity actualize the need for psychological research in the field of economic consciousness and economic representations of the individual in order to find ways of psychological support for students at the stage of receiving professional education. The article analyzes the scientific category of economic consciousness, its structure and the role of economic ideas of it. The economic views of the university students $(N=110)$ on the representation on the wealth, rich people, money, poverty, property, economic risk, competition, preferred form of work organization were considered in the empirical study on the basis of the higher educational institution in the sociocultural conditions of the Chuvash Republic (Russian Federation). The results of the research will become the basis for the development of scientifically based recommendations on the formation in the education sector of economic representations of future specialists as a means of increasing the efficiency of training specialists at the university.
\end{abstract}

Keywords- economic representations; economic consciousness; student youth; representations about wealth and poverty; representations about ownership and competition

\section{INTRODUCTION}

Modern Russian society is in the process of significant socio-economic, sociocultural transformational changes, the creation of new economic conditions for life, the formation of fundamentally new social relations. Subjective perception of a

\author{
V.L. Semenov \\ Chuvash state University \\ Cheboksary, Russia
}

\author{
G.S. Dulina \\ Chuvash state University \\ Cheboksary, Russia
}

person reflects these changes and is, on the one hand, a serious indicator of the country's economic and political development, and on the other hand, a factor that determines the behavior of a person in the field of the economy. This determines the priority and urgency of expanding research on the economic consciousness of various groups of the population.

Analysis of the history of the study of the scientific category of economic consciousness shows that economic consciousness was viewed in the Russian philosophy and sociology as a substructure of public consciousness as a whole, as a separate level of consciousness, the formation of which is determined by the economic structure characteristic of people in the given economic formation $[4,17]$.

In the opinion of A. K. Uledov [22], economic consciousness is a product of people's reflection of the economic conditions of life, activity and relationships in the form of economic ideas and views, theories and concepts and other spiritual entities common to groups, social groups, the whole society and expressing their relation to economic reality at every particular historical moment

S. N. Apenko and V. Yu. Mamaeva that the economic consciousness, firstly, plays the role of an "intermediary" between objective conditions and real actions of people; secondly, it reflects the objective situation not passively, as the process of reflection is influenced by views, beliefs, attitudes (including those formed in the past). These authors propose to define economic consciousness as existing in the form of scientific knowledge reflecting natural processes and relationships; values and norms, regulating the behavior and activities of people; goals and objectives that show the desired 
performance in the future, preferences, tastes, moods, emotions, creating a certain background effect.

A. V. Filippov and S. V. Kovalev [3] defined economic consciousness in the research perspective of economic psychology as the highest level of mental reflection of economic relations by a socially developed person.

A. L. Zhuravlev and N. A. Zhuravleva [31] suggest considering economic consciousness as social representations, attitudes, assessments, opinions of the person and etc. about various phenomena of economic content (economic objects). The authors underline the socio-psychological essence of this phenomenon and distinguish its following functions: first, the reflection of the socio-economic conditions of life, the economic macro- and microenvironment, and second, its ability to act as one of the psychological regulators of a person's economic behavior in a social environment.

Economic consciousness is determined by the objective need to understand the ongoing socio-economic changes and is formed under the influence of actual historical conditions. The economic consciousness of society reflects the understanding of the relationship between economic activity and those social, political and legal conditions in which human economic activity is carried out.

The economic consciousness of the individual, in the opinion of such authors as A. D. Karnyshev, T. D. Burmenko, E. A. Ivanova [7] is a set of views, attitudes toward fundamental individual and social economic values, its place and role in economic structures. Economic consciousness concerns all spheres of economic life, in which the individual interacts with other people in different ways. Economic consciousness in a number of its characteristics is usually differentiated depending on the level of wealth and poverty, social status, professional group, place of residence and a number of other factors.

The question of the structure of economic consciousness is ambiguous.

A. V. Filippov and S. V. Kovalev [3] understand the structure of economic consciousness "as a set of constructs where economic relations are reflected", distinguish in it the following substructures: 1) constructs that generalize the economic order, economic arrangement, existing as a relationship between a man and society; 2) constructs explaining the order visible to the subject in the most general form; 3) constructs of ideal economic relations - "economic dream"; 4) constructs of long-term orientation, providing behavior in specific recurring situations and regulating everyday relationships; 5) constructs to achieve the goals of economic activity as a self-worth; 6) constructs of economic measurements, which can best be represented in the analysis of economic thinking.

O. A. Deineka [2] considers under the economic consciousness the systemic component of consciousness, the highest level of mental reflection of economic relations by a socially developed person, proposes to distinguish the following components of the structure: economic emotions and feelings, the perceptive sphere of economic behavior; economic ideas and economic thinking; volitional components of economic consciousness - economic norms, economic interest.

According to Z. Z. Vakhitova [24], economic consciousness acts as a complex entity that, in the first place, contains a cognitive component that acts in the form of ideas, attitudes, stereotypes, etc.; second, as the affective component, expressed through the relationship of man to the facts and phenomena of economic life, existing in the form of assessments, emotions; third, as the behavioral component, in the form of norms and strategies of economic behavior and people's activities.

E. S. Shibanova and V. A. Hashchenko [19] distinguish such structural components in the structure of economic consciousness as: 1) the person's representation of himself as an economic subject (subjective economic status, economic self-identification, economic claims, ideas about opportunities increase of incomes, self-esteem, business success, etc.); 2) ideas about wealth (subjective economic welfare, subjective income scale, etc.); 3) the attitude towards rich and poor people; 4) the attitude towards money; 5) the attitude of a person to property; 6) views on forms of management (economic behavior, ways of achieving material prosperity); 6) the attitude to competition, the man's attitude to economic values, etc.

A. L. Zhuravlev and N. A. Zhuravleva [32] refer to the components of economic consciousness as follows: 1) the person's self-image as an economic subject, including subjective and economic status, satisfaction with the level of material well-being, level of economic claims, the representation of the individual about his business activity and satisfaction with the level, the idea of his opportunities in raising incomes, ways of the increase; 2 ) representation of the person about material well-being and wealth, an attitude to rich and poor people; 3) social attitudes of the person to various forms of economic behavior - consumer, saving, entrepreneurial, investment, charitable; 4) the relation of a person to money; 5) representing people about incomegenerating activities; 6) the idea of the owner; 7) orientation of the individual to economic values.

O. S. Deineka [2] discloses four components of consciousness: 1) economic thinking, economic concepts; 2) sensations and perceptions in the economic sphere; 3) economic norms and interests, economic motives; 4) feelings and emotions in the economic sphere. The first and second components of the proposed scheme perform the function of reflecting the objective economic reality, they participate in the creation of the model of the economic sphere of life. The third and fourth components perform the function of regulation, they participate in changing the material side of the surrounding world. In this case, the first and third components represent a level of active reflection and active regulation, they rely on the second and fourth components that perform reactive reflection and reactive regulation and incorporate them into themselves.

According to the authoritative scholar in the field of economic psychology V. A. Khashchenko's [7] economic views are the basic component of the economic consciousness of the individual, forming a subjective model of the economic 
well-being of a person characterized by the unity of material (attributes), financial (poverty and wealth borders) and psychological (goals, means, personal qualities) factors.

T. P. Emelyanova considers the function of economic representations as a group phenomenon from the point of adaptation of the individual and the group to the surrounding economic world [26].

Thus, economic concepts play an important and significant role in the structure of the economic consciousness of the individual.

Scientists based on the results of a series of empirical studies on the analysis of socio-psychological problems and the consequences of economic reform, launched in Russia in 1992, revealed that under the conditions of radical economic changes, individuals and groups are not the passive objects of the changes that are occurring, but are their active subjects. The phenomenon of preferring the form of ownership and the type of economic activity is formed at the personal level of psychological relations [30].

The study of the economic consciousness of student youth as future enterprise managers, of firms and organizations as potential entrepreneurs is of special scientific interest.

The research of scientists A. L. Zhuravleva and A. B. Kupreychenko [28] showed that the components of economic consciousness and self-awareness of students in the process of professionalization in the university are quite dynamic. This dynamics reflects changes in life priorities, goals, selfassessment of abilities and opportunities to achieve these goals, as well as other components of self-determination of the individual, for example, attitudes towards people, social groups and society as a whole. The patterns of the process of economic socialization and the influence of professional orientation are shown in the dynamics of social ideas about the wealth of student youth.

In the work of N. V. Miromanova [15] the similarities and differences in perceptions of poverty and the wealth of students and the working population were studied. It was found that the notions of poverty in both age groups are similar, despite the influence on the formation of the personalities of the subjects of different economic events in the country. The understanding of wealth was different in the group of working students and student youth.

The results of the study of T. P. Emelyanova, T.V. Drobysheva [26] of features of social perceptions of poverty among Russian students and elderly people (people of low income) showed that their emotional self-awareness (happiness) and satisfaction with material situation are at a level of above average, and they actively dissociate themselves from the category of "poor", who are associated with negative social and personal traits. Poverty as a social phenomenon is the subject of emotionally loaded reflections, so respondents do not consider themselves to be poor people. The current small financial opportunities for students are perceived as only a transitory stage of life. Their orientation to a future comfortable and interesting life does not allow the thought that they belong to the category of the poor, to whom they feel antipathy.
In the study of D. A. Kitova, B. A. Naymanova [10, 11], it is shown that in the production of images of that program, the forthcoming economic activity in the creation of images that correspond to descriptions of economic objects, phenomena and states, they serve as the initial tools for representing ways to achieve material prosperity. The concept of achieving economic prosperity in the main features has already been formed, but due to objective and subjective reasons, it often proves to be contradictory and inadequate to the conditions of market relations in the structure of the representations of the vast majority of students, This is due to the fact that the corresponding concept is developed on the basis of understanding of the economic conditions of life of the nearest social environment (family and surrounding people). The largest number of selected ways of economic well-being has a legitimate character and fits in generally accepted social norms (get a well-paid job, open one's business, buy shares, give money at interest, go to big sport, put forward an original and perspective idea, etc.). Students distinguish three ways to achieve material prosperity: wage labor, entrepreneurship and individual employment. At the same time, the authors have also revealed distortions in economic ideas: plans for achieving economic prosperity are, to a large extent, of dependent nature; they do not orient the individual to economic activity based on an independent economic initiative.

Social concepts of wealth and poverty, ways to achieve prosperity in modern conditions have significant socio-cultural and regional characteristics $[9,19,21]$.

This is due to the fact that a significant part of the established positions of the economic consciousness has an ethnohistorical character, it reflects the historically formed mentality of the people and the features of the worldview of ethnos that is the characteristic of it during a long historical period. Many scholars analyzing the peculiarities of the Russian, "Soviet" and "post-Soviet" mentality show that the mentality of the Russian people, rooted in the distant past, is non-market-based. It is characterized by the secondary nature of material and economic factors, the priority of collective and intangible values over the values of individual well-being, a high role of non-economic factors of success, moral, spiritual incentives to work; traditions of attitudes towards wealth, property in the spirit of collectivism and community, a high commitment to the principles of income equality and the rejection of private property, the pursuit of social justice. One of the significant features of the Russian mentality is the contradictory attitude of a part of the population towards such economic values as wealth, money, property. A tolerant attitude towards the poor was developed, the ideal of poverty was cultivated, and at the same time, the rejection of wealth. These features were reinforced by religious beliefs about wealth in Orthodoxy.

In the studies of T. M. Uzdenov [23], it is shown that students' ideas about ways to achieve economic well-being are the result of the influence of the sociocultural environment, personal experience, the experience of the closest environment. It creates an ultimately minimized picture of the world in which the subjective activity concept of achieving economic well-being, characterized by the appropriate 
purpose, motive, ways of action and the anticipated (expected) economic and psychological result, i.e. economic representations are interconnected with socio-cultural characteristics. The author has revealed that students' ideas about ways to achieve economic well-being have individual and typical features: individual features reflect subjective knowledge about the types and forms of activity that ensure economic success, and typical features reflect group experience, actually contained in the constructs of mass (everyday) consciousness.

The socio-cultural nature of the structure of social notions of well-being was revealed in a study by O. S. Masharskaia [14]. The structure of social notions of well-being and the nature of the interconnection of its components had crosscultural differences depending on the nationality of the students (Russian, Belarusian and American students), along with gender and marital status.

Thus, the study and monitoring [12] of the economic views of student youth as future professionals and active participants in the dynamically changing economic life of society is of special scientific interest.

\section{MATERIALS AND METHODS}

The purpose of the study is to study economic ideas in the structure of the economic consciousness of student youth in the context of the transformation of modern society.

\section{Research quesions}

1) What are the economic representations of student youth about wealth, attitude to rich people, money?

2) What are the economic views of university students about poverty?

3) What are the economic ideas about the preferred form of organization of work and the direction to create one's own business?

4) What are the economic representations of student youth about their willingness to work in a competitive and economic environment?

\section{Methods}

A number of questions were used to assess the respondent's economic views from a standardized program of socio-psychological research of an individual's economic consciousness in this study [30-32].

These economic representations are aimed at studying the nature of social motivation for actions that promote or impede economic transformation; orientation of social attitudes on the basis of which one or another type of real economic behavior develops, etc., and in many respects they express essential features, the development measure of which will determine the type of economic consciousness and economic behavior of a person in the current economic situation: active or passive, modern or conservative, effective or inefficient, etc.

We considered economic concepts of choice to have a major business, even if connected with economic risk, preferring to have one's own business, which requires a great deal of effort, but in case of success, bringing a significant income; economic ideas associated with the orientation toward creating one's own business and professional self-realization; positive perception of wealth and wealthy people; psychological readiness to work in conditions of competition and economic risk as an orientation to the active type of economic consciousness and behavior.

We considered the respondents' opinions about the preference "to have not very large but stable earnings"; negative perception of wealth and wealthy people; psychological unpreparedness to work in conditions of competition and economic risk as an orientation to a passive type of economic consciousness and behavior that does not require independence, initiative.

The results were discussed during an interview with student youth after the survey.

\section{RESULTS AND DISCUSSIONS}

The study was conducted in the sociocultural conditions of the Chuvash Republic (Russian Federation) on the basis of the University in Cheboksary.

110 students took part in it: 57 girls and 53 boys, aged 18$22(19.01 \pm 0.82$ years old $)$

Scientists believe [13] that it is extremely important to consider the influence of two phenomena - wealth and poverty, as establishing the extreme limits of the possible arrangement of a person or a social group in order to understand the situation in the society. They are understood as a kind of reference points that allow determining the place of the individual in society, and, at the same time, powerful motivating factors - the pursuit of wealth and attempts to escape poverty.

An attitude to wealth in our study was considered through social notions of wealth and an attitude towards rich, wealthy people.

What is expressed by the wealth in the opinion of students? It is known that the notions of wealth are related to the level of social maturity and express the person's orientation toward certain goals, professional self-realization or care of close people [28].

For most respondents, the social notions of wealth are associated with a profitable business $(40 \%)$ and a highly paid job $(22 \%)$, i.e. is associated with the orientation of making money in the process of professional self-realization.

For $11 \%$ of students, the most significant sign of wealth was the opportunity to help relatives.

$10 \%$ of students consider the notion of wealth as a level of welfare that allows satisfying basic consumer needs (the answer is "the opportunity not to think about tomorrow").

$5 \%$ of students have a stereotypical understanding of wealth as a category that means owning something, associating wealth with the availability of a fashionable machine, furniture and clothing. 
Representations of wealth as the availability of real estate, currency, jewelry; the ability to travel or make donations is almost not characteristic of this study.

It was revealed in a number of studies on a similar topic that young people of early age - representatives of the younger generation, demonstrate thinking, limited by the framework of the consumer society and the ideals of consumerism. Wealth was usually associated with the opportunity to purchase better quality goods (clothes and footwear, food products), to have more comfortable housing [13]. In our study, the most significant ideas were the ones that motivate for economic and professional activity, and not the ideals of consumerism.

To study the attitude to rich people, the respondents were asked the following questions: "Do you think the most of the people around you are wealthy people?", "How do you personally feel about rich, wealthy people?" The answers were grouped by levels (high, medium, low).

The majority of respondents noted a high level of subjective assessment (approving) of attitudes towards rich, financially well-off people (Table 1). For the entire sample, as well as for boys and girls, this indicator is at a high level from 40 to $42 \%$, on average - from 33 to $43 \%$.

About a fifth of our respondents are ready to take rich people more negatively; this indicator is higher among girls (26\%).

TABLE I. ATTITUDE TOWARDS RICH, WEALTHY PEOPLE

\begin{tabular}{|c|c|c|c|}
\hline total sample & \multicolumn{3}{|c|}{ Level } \\
\cline { 2 - 4 } & Low & Medium & High \\
& $\%$ & $\%$ & $\%$ \\
\cline { 2 - 4 } & 22 & 37 & 41 \\
\hline boys & 17 & 43 & 40 \\
\hline girls & 26 & 32 & 42 \\
\hline
\end{tabular}

Thus, the prevailing widespread view that there is a feeling of envy for rich people who have a lot of money was not confirmed in our research.

The phenomenon of poverty is represented by respondents as lack of sufficient means of subsistence $(59.1 \%)$, associated with a lack of normal housing conditions (9.1\%), total uncertainty in the future $(10 \%)$, with a constant life in debt $(8.2 \%)$

Less than 5\% indicated such answers as "living on a living wage", "having a low-paid job", "having only the necessary minimum of products to support living", "lack of opportunities to live as you like", "lack of a stable source of income". The options "lack of savings" and "no possibility to use paid services" were not chosen at all.

An attitude to property is social representations of the individual about the attributive characteristics of the owner. Respondents understand the property as: the availability of large cash $(27.3 \%)$, real estate, profit $(22.7 \%)$, a large apartment $(20 \%)$, etc. Such signs of the owner as "capital in a profitable business", "securities of banks, enterprises", "house with a site", "private enterprise", "bank account" were indicated by less than $5 \%$ of respondents (Table 2).

Students are not ready for risk in investment behavior, which can indicate both a lack of money for investment and unformed views on the benefits of investing free cash, a certain degree of confidence in the economic and political situation in the state.

\section{TABLE II. CHARACTERISTICS OF THE OWNER}

\begin{tabular}{|c|c|c|c|c|c|c|c|}
\hline \multirow[t]{2}{*}{ No. } & \multirow{2}{*}{$\begin{array}{l}\text { Property } \\
\text { characterist } \\
\text { ics }\end{array}$} & \multicolumn{2}{|c|}{ sample } & \multicolumn{2}{|l|}{ boys } & \multicolumn{2}{|c|}{ girls } \\
\hline & & abs. & $\%$ & abs. & $\%$ & abs. & $\%$ \\
\hline 1. & $\begin{array}{l}\text { Large } \\
\text { amounts of } \\
\text { money }\end{array}$ & 30 & 27.3 & 17 & 32.1 & 13 & 22.8 \\
\hline 2. & $\begin{array}{l}\text { Property that } \\
\text { brings profit }\end{array}$ & 25 & 22.7 & 17 & 32.1 & 18 & 31.6 \\
\hline 3. & $\begin{array}{l}\text { Large } \\
\text { apartment }\end{array}$ & 22 & 20 & 11 & 20.8 & 11 & 19,3 \\
\hline 4. & $\begin{array}{l}\text { The car, } \\
\text { garage, } \\
\text { valuables }\end{array}$ & 10 & 9.1 & 7 & 13.2 & 3 & 5.3 \\
\hline 5. & $\begin{array}{l}\text { Gold, } \\
\text { valuables, } \\
\text { currency }\end{array}$ & 7 & 6.4 & 3 & 5.7 & 4 & 7.0 \\
\hline
\end{tabular}

According to scientists, proceeding from the fact that among the main manifestations of Russian polymentality. there is the orientation toward collectivism, which often contradicts the requirements of the new economic time, students as future professionals in their business were asked to indicate the preferred form of economic behavior.

The majority of respondents $(49.1 \%)$ prefer to work in a small team of well-known people $(47.2 \%$ of boys, $50.9 \%$ of girls). $28.2 \%$ of the students want to work individually (34\% of boys, $22.8 \%$ of girls). $17.3 \%$ of the respondents prefer to work in the collective of a large enterprise (13.2\% of boys and $21.1 \%$ of girls). Less respondents would like to have business with their family members $-5.5 \%$ of the students surveyed.

An attitude to economic risk is the degree of the individual's desire to take economic risk. This criterion is expressed in a subjective assessment of psychological readiness for risk in the economic sphere of activity. To a greater extent, respondents expressed an average level of psychological readiness for competition with other people in the economic sphere. $84 \%$ of the students in the survey showed it: $85 \%$ of boys and $84 \%$ of girls. Students are not inclined to take a big risk for raising incomes, as they are in most cases dependent on their parents. Not economic goals are the most important for them at this stage of life

To identify economic ideas related to economic and business activity, several options were offered: 1. Have a relatively small but stable income; 2 . Have your own business, 
which will require a great deal of effort, but if successful, will bring a significant income; 3 . Have a major business related to economic risk.

When identifying economic behavior associated with active economic activities and a certain economic risk, it was revealed that "57.3\% of students want to" have their own business that will require a great deal of energy, but if it succeeds, it will bring significant income."

$10 \%$ of the surveyed sample were those young people who wanted to have a major business related to economic risk.

Those who represent their economic future in order to have not a very large but stable income (that is, with a low level of economic risk) make $30 \%$ of student youth. These answers turned out to be almost the same among girls and boys.

Thus, as a result of the analysis of economic attitudes, students identified attitudes both to economic paternalism and to economic independence.

An attitude to money is a subjective assessment of the significance of money. These studies indicate an average level of attitudes toward money. The significance of money for the individual, its value for the general sample is $61 \%$, for young men $-70 \%$ and for girls $-52.6 \%$. Money is important in the life of future specialists, but it does not play a dominant social and economic role.

Economic notions of competition are important in today's changing world. Modern society is experiencing an acute need for competitive specialists capable of maintaining equal or higher professional standards than competitors in a dynamic market environment. However, according to ongoing research, some graduates of universities are not ready to work in conditions of uncertainty of economic reality. Such young specialists may not be psychologically able to change the profile of their activities under the changed strategy of enterprise development and the development of technologies. They are not able to show flexibility in thinking to resolve competitive situations.

In our study, the majority of respondents $-65.5 \%(64.2 \%$ of boys and $66.7 \%$ of girls) - assess their desire for competition with other people as an average, neutral ("everything happens: I compete sometimes and I do not compete sometimes"). $13.7 \%$ of respondents (16.9\% of boys and $10.6 \%$ of girls) expressed a low level of readiness for a competitive environment (the answers "this feeling is absolutely alien to me" and "I just do not like competitions"). A high level of readiness for competition, which we understand as a sign of personal competitiveness, was demonstrated by $21 \%$ of university students (the answers "I like to compete with people" and "I prefer to live and work in conditions of competition"). This indicator is slightly higher for girls (18.8\% of young men and $22.8 \%$ of girls). Such young specialist, in addition to learning good knowledge and skills in the field of his profession, will be psychologically more willing to work in the constantly changing conditions of a competitive environment.

According to the results of the survey, all respondents are classified into three groups: with an active, medium, passive type of economic consciousness and behavior. Recommendations were proposed for each of the groups. $20 \%$ of the respondents are oriented to the active type of economic consciousness and behavior. They have representation of economic notions of choice to have a big deal, even if associated with economic risk; preferences to have one's own business, demanding a great deal of strength, but in case of success, bringing a significant income; economic ideas associated with the orientation toward creating one's own business and professional self-realization; positive perception of wealth and wealthy people; psychological readiness to work in conditions of competition and economic risk.

$30 \%$ of the respondents have an orientation toward a passive type of economic consciousness and behavior. It does not require independence, initiative, the respondents' judgments about the preference "to have not very large but stable earnings"; negative perception of wealth and wealthy people; psychological unpreparedness to work in conditions of competition and economic risk.

\section{CONCLUSIONS}

Analysis of scientific sources revealed that economic representations play an important and significant role in the structure of the economic consciousness of the individual. Such economic representations of the individual as the perception of material well-being and wealth, an attitude to rich and poor people, to money; social attitudes of the individual to various forms of economic behavior and forms of management; representation of the owner; an attitude to competition and economic risk can become decisive in the formation of an active type of economic consciousness and economic self-determination inherent in effective leaders, businessmen, entrepreneurs.

The study of the economic consciousness of student youth as future managers of enterprises, firms and organizations, as potential entrepreneurs is of special scientific interest. Instability and complication of the economic environment of a person's life activity actualize the need for psychological research in the field of economic consciousness and economic representations of the individual in order to find ways of psychological support for students at the stage of receiving professional education.

Formation of economic representations of students in the study of disciplines of the economic and socio-psychological cycle can be considered as one of the important areas of work in the university. It requires close attention and development of conditions, means of its implementation.

The conducted empirical research has shown that economic representations of the majority of the students are connected with the positive relation to the rich, financially secured people. They have the ideas about wealth, motivating to economic and professional activity, and not to the ideals of consumerism. They are at the prevailing average level of subjective assessment of the degree of significance of money. They have the focus of work in a competitive environment and economic risk. 
According to the results of the survey, all respondents are classified into three groups: an active, medium, passive type of economic consciousness and behavior. As a result of the analysis of economic attitudes, Russian students have attitudes to both economic independence and economic paternalism. Recommendations were proposed for each of the selected groups in three areas - educational, training and consulting.

The results of the research became the basis for the development of scientifically grounded recommendations for the formation of economic representations of future specialists as a means of improving the efficiency of training specialists in the sphere of education of the university.

\section{References}

[1] A.Yu. Aleksandrov, A.N. Zakharova, E.L. Nikolaev, "New Challenges in Engineering Education: Personal Advancement for Better Marketability of Future Professionals", International Conference on Interactive Collaborative Learning, pp. 452-454, 2015, [International Conference on Interactive Collaborative Learning Italy, 2456, 2015].

[2] O.S. Deyneka, "Ekonomicheskaya psikhologiya", SPb.: Izd-vo SPbGU, 1999, pp. 37-39

[3] A.V. Filippov, S.V. Kovalev, 'Psikhologiya i ekonomika", Psikhologicheskiy zhurnal, № 1, p. 28-29, 1989.

[4] V.P. Fofanov, "Ekonomicheskiye otnosheniya i ekonomicheskoye soznaniye", Novosibirsk: Nauka, 1979

[5] V. A. Kol'tsova, Ye.V. Kharitonova, "Istoriogenez i sovremennoye sostoyaniye rossiyskogo mentaliteta", M.: Izd-vo «Institut psikhologii RAN», 2015, $479 \mathrm{p}$

[6] A. L. Zhuravlev, V. A. Kol'tsova, Ye. N. Kholondovich, "Istoriogenez i sovremennoye sostoyaniye rossiyskogo mentaliteta",Vol.2, M.: Izd-vo «Institut psikhologii RAN», 2016, $487 \mathrm{p}$

[7] A.D. Karnyshev, T.D. Burmenko, E.A. Ivanov, "The person and the property", Irkutsk: Publishing house BGUEP, 2006, p.27

[8] V.A. Khashchenko, "Ekonomicheskaya identichnost' lichnosti: psikhologicheskiye determinanty formirovaniya", Psikhologicheskiy zhurnal, v. 25, №5, pp. 32-49, 2004

[9] V.A. Khashchenko., Ye.S. Shibanova, "Predstavleniya o bogatstve i bednosti $\mathrm{v}$ razlichnykh sotsial'no- ekonomicheskikh usloviyakh zhizni: regional'nyy aspekt", Problemy ekonomicheskoy psikhologii, M.: Izd-vo «Institut psikhologii RAN», v.2. pp. 476-510, 2005.

[10] D.A. Kitova, B. A. Naymanova, "Pravovyye aspekty v predstavleniyakh studentov o sposobakh dostizheniya ekonomicheskogo blagopoluchiya", Vestnik Universiteta Rossiyskoy akademii obrazovaniya, 2016, № 1. pp. 87-91.

[11] D.A. Kitova, T.M. Uzdenov, "Predstavleniya studentov o tselyakh i sredstvakh dostizheniya ekonomicheskogo blagopoluchiya", Gumanizatsiya obrazovaniya, 2009. №3, pp. 129-133.

[12] R.A. Kutuev, N.A. Mashkin, O.G. Yevgrafova, A.V. Morozov, A.N. Zakharova, V.T. Parkhaev, "Methodological guidance of educational monitoring effectiveness", Modern Journal of Language Teaching Methods, v. 7. № 3. pp. 405-410, 2017.

[13] S.V. L'vov, "Obrazy bednosti i bogatstva v rossiyskom obshchestvennom soznanii", Monitoring obshchestvennogo mneniya: ekonomicheskiye i sotsial'nyye peremeny, 2007, (1 (81)), pp.34-44.

[14] O.S. Masharskaya, "Krosskul'turnyye razlichiya sotsial'nykh predstavleniy studentov o blagopoluchii", Avtoreferat diss. ... k-ta psikhol. n. Kursk, 2012

[15] N.V. Miromanova, "Izucheniye predstavleniy o bogatstve i bednosti u rabotayushchego naseleniya i studencheskoy molodezhi”, Psikhologiya v ekonomike i upravlenii, 2013 (2), pp.18-22.
[16] N.S. Morova, T.V. Talanova, T.V. "Ethnocultural and social dominants of pedagogical education in conditions of national region", Review of European Studies, 7 (8), pp.182-188, 2015.

[17] V.D. Popov, "Ekonomicheskoye soznaniye: sushchnost', formirovaniye rol' v sotsialisticheskom obshchestve", M.: Mysl', 1981.

[18] O.V. Shevtsova, "Sootnosheniye sotsial'nogo kapitala s ekonomicheskimi ustanovkami, predstavleniyami i modelyami ekonomicheskogo povedeniya", Sovremennyye nauchnyye issledovaniya i innovatsii, № 4, pp.34-38, 2012

[19] Ye.S. Shibanova, V.A. Khashchenko, "Predstavleniya o bogatom bednom cheloveke $\mathrm{v}$ razlichnykh sotsial'no-ekonomicheskikh gruppakh", Sovremennaya psikhologiya: sostoyaniye i perspektivy issledovaniy, vol. 2, Obshchaya i sotsial'naya psikhologiya, psikhologiya lichnosti, psikhofiziologiya, ekonomicheskaya, organizatsionnaya i politicheskaya psikhologiya: materialy yubileynoy nauch. konf. IP RAN, p. 334, .28-29 January 2002 [Obshchaya i sotsial'naya psikhologiya, psikhologiya lichnosti, psikhofiziologiya, ekonomicheskaya, organizatsionnaya i politicheskaya psikhologiya, Moscow, 2002]

[20] Ye. D. Slobodenyuk, "Faktory absolyutnoy i sub"yektivnoy bednosti v sovremennoy Rossii", Vestnik obshchestvennogo mneniya. Dannyye. Analiz. Diskussii, 2016, № 3-4, pp. 82-92.

[21] A.N. Tatarko, "Cotsial'nyy kapital i ekonomicheskiye predstavleniya russkikh i kitaytsev: razlichiya i vzaimosvyaz"', Psikhologiya. Zhurnal Vysshey shkoly ekonomiki, vol. 7, № 1. pp. 138-148, 2010.

[22] A.K. Uledov, "Obshchestvennaya psikhologiya i ideologiya", M.: Mysl', 1985 , p. 31

[23] T.M. Uzdenov, "Predstavleniya studentov o sposobakh dostizheniya ekonomicheskogo blagopoluchiya", Avtoreferat diss. ... k-ta psikhol. n GOU VPO «Karachayevo-Cherkesskiy universitet imeni U.D. Aliyeva», 2010 .

[24] Z.Z. Vakhitova, "Sotsial'no-psikhologicheskiye osobennost vospriyatiya sub"yektov ekonomicheskikh otnosheniy: Na primere nayemnykh rabotnikov i predprinimateley". Dis. ... kand. psikhol. nauk 19.00.05. M. RGB, 2003, p.14

[25] M.V. Yefremova, "Osobennosti ekonomicheskikh ustanovok predstavleniy u moskovskikh studentov", Vestnik Universiteta (Gosudarstvennyy universitet upravleniya), № 5. pp. 34-36, 2009.

[26] T. P. Yemel'yanova, T. V. Drobysheva,"Osobennosti sotsial'nykh predstavleniy o bednosti u studentov i pozhilykh lyudey", Informatsionnyy gumanitarnyy portal «Znaniye. Ponimaniye. Umeniye», 2013, № 3, p.68.

[27] T. P. Yemel'yanova, "Konstruirovaniye sotsial'nykh predstavleniy v usloviyakh transformatsii rossiyskogo obshchestva", M.: Institut psikhologii RAN, 2006, $400 \mathrm{p}$

[28] A.L. Zhuravlev, A.B. Kupreychenko, "Ekonomicheskoye samoopredeleniye: Teoriya i empiricheskiye issledovaniya", M.: Izd-vo «Institut psikhologii RAN», 2007.

[29] A.L. Zhuravlev, V.P. Poznyakov, "Programma sotsial'nopsikhologicheskogo issledovaniya rossiyskikh predprinimateley", Sovremennaya psikhologiya: sostoyaniye i perspektivy issledovaniy. pp. 90-110, 2002.

[30] A.L. Zhuravlev, V.P. Poznyakov, "Sotsial'naya psikhologiya ekonomicheskiye reformy v Rossii", Psikhologicheskiy zhurnal, 2018. v. 39. № 1. pp. 15-25.

[31] A.L Zhuravlev, N.A. Zhuravleva, "Dinamika ekonomicheskogo soznaniya rossiyskikh predprinimateley v 90-ye gody XX veka", Sovremennyye problemy psikhologii upravleniya, M.: Izd-vo «Institut psikhologii RAN», 2002. pp. 126-127.

[32] A.L. Zhuravlev, N.A. Zhuravleva, "Programma sotsial'nopsikhologicheskogo issledovaniya ekonomicheskogo soznaniya lichnosti”, Sovremennaya psikhologiya: Sostoyaniye i perspektivy issledovaniy. vol. 5, M.: Izd-vo IP RAN, 2002. pp. 11-42. 